\title{
A multi-ootaxic assemblage from the Lower Cretaceous of the Cameros Basin (La Rioja; Northern Spain)
}

\author{
Miguel MORENO-AZANZA', ${ }^{1,2}$, José Manuel GASCA ${ }^{2,3}$, Ignacio DÍAZ-MARTÍNEZ ${ }^{4}$, Blanca \\ BAULUZ LÁZARO ${ }^{5}$, José Ignacio CANUDO SANAGUSTÍN ${ }^{2}$, Arturo FERNÁNDEZ ${ }^{6}$ \& \\ Félix PÉREZ-LORENTE ${ }^{7}$
}

\footnotetext{
${ }^{1}$ Departamento de Ciências da Terra, Geobiotec. Departamento de Ciências da Terra. Faculdade de Ciências e Tecnologia, FCT, Universidade Nova de Lisboa, 2829-526. Caparica, Portugal. Museu da Lourinha; mmazanza@fct.unl.pt

${ }^{2}$ Grupo Aragosaurus-IUCA, Paleontología, Facultad de Ciencias, Universidad de Zaragoza, Pedro Cerbuna 12, 50009 Zaragoza, España; jicanudo@unizar.es

${ }^{3}$ CONICET-Museo Provincial de Ciencias Naturales "Profesor Dr. Juan A. Olsacher", Zapala, 8340 Neuquén, Argentina; jmgaska@hotmail.com

${ }^{4}$ CONICET-Instituto de Investigación en Paleobiología y Geología, Universidad Nacional de Río Negro, General Roca 1242, 8332 Argentina; inaportu@hotmail.com

${ }^{5}$ Mineralogía y Cristalografía, Facultad de Ciencias, Universidad de Zaragoza, Pedro Cerbuna 12, 50009 Zaragoza, España; bauluz@unizar.es

${ }^{6}$ Asociación de Amigos del Museo de Enciso (AME), Poyales 26586 Enciso (La Rioja); eldinocojuelo@gmail.com

${ }^{7}$ Universidad de La Rioja, Edificio CT, c/Madre de Dios, 51-53, E-26006 Logroño, España; felix.perez@unirioja.es

* Corresponding author
}

Moreno-Azanza, M., Gasca, J.M., Díaz-Martínez, I., Bauluz Lázaro, B., Canudo Sanagustín, J.I., Fernández, A. \& PérezLorente, F. 2016. A multi-ootaxic assemblage from the Lower Cretaceous of the Cameros Basin (La Rioja; Northern Spain). [Una asociación multi-ootáxica del Cretácico Inferior de la Cuenca de Cameros (La Rioja; Norte de España)]. Spanish Journal of Palaeontology, 31 (2), 305-320.

\section{ABSTRACT}

Here we describe the new fossil site of El Horcajo in the vicinity of Trevijano (La Rioja, Spain). It is located in the palustrine facies of the Enciso Group (Cameros Basin). This new locality has provided dozens of eggshell fragments, together with other vertebrate remains and charophyte fructifications, which allow dating of the locality as Valanginian-Hauterivian. Five ootaxa have being recognized: 1) the Spheroolithidae Guegoolithus turolensis; 2) a surprisingly thick Prismatoolithidae indet., with certain affinities to the oogenus Sankofa, that may represent a new oogenus and oospecies for this oofamily; 3 ) the Krokolithidae

\section{RESUMEN}

En este trabajo se describe el nuevo yacimiento fosilífero de El Horcajo en las cercanías de Trevijano (La Rioja, España). Se encuentra en facies palustres dentro del Grupo Enciso (Cuenca de Cameros). Este nuevo yacimiento ha proporcionado docenas de fragmentos de cáscara de huevo, junto con otros restos fósiles de vertebrados y fructificaciones de carofitas, que permiten datar el yacimiento como ValanginienseHauteriviense. Se han identificado cinco ootaxones: 1) Guegoolithus turolensis, de la oofamilia Spheroolithidae; 2) un Prismatoolithidae indet. sorprendentemente grueso y con afinidades al oogénero Sankofa, que podría corresponder 
Krokolithes sp.; 4) recrystallized ?Testudoolithidae eggshells; and 5) ?Geckoolithidae eggshells of uncertain affinity. This oodiversity is similar to that of other eggshell microsites. The ootaxonomic list differs from the other Iberian locality of the same age, Pochancalo 1 (Villanueva de Huerva Formation, Zaragoza) in lacking sauropod and megalosauroid theropod eggshells, but shares the presence the ornithopod and coelurosaurian theropod eggshells with other younger microsites found in similar facies. The age of the new locality has immediate consequences for the tectono-sedimentary framework of the Cameros Basin, and the new data will need to be considered in future stratigraphical works. Furthermore, the reliability of eggshells as biostratigraphic markers is questioned, and the viability of Guegoolithus as a guide fossil for the lower Barremian is rejected.

Keywords. Valanginian-Hauterivian, Enciso Group, vertebrate eggshells, dinosaurs.

\section{INTRODUCCTION}

Although complete eggs are yet unknown, eggshell fragments are relatively common in the Lower Cretaceous of Spain. They are a common component in most of the microvertebrate sites described in the recent years (Köhring, 1990; Buscalioni et al., 2008; Canudo et al., 2010; Gasca et al., 2012; Ruiz-Galván et al., 2014) and have revealed a previously unknown oodiversity (MorenoAzanza et al., 2009, 2014a, 2014b, 2015).

Contrasting with this high abundance of localities in the Iberian Chain, the neighboring Cameros Basin has not provided any eggshell localities from the Lower Cretaceous outcrops, although a few sites are known in the Upper Cretaceous (Moratalla, 1993; Izquierdo et al., 1999; Bravo et al., 2006). Recently, eggshell fragments have being recognized in thin sections of calcareous rocks of the Leza Formation (Suárez-González et al., 2013). These eggshells have not been studied in depth, but the presence of an eggshell fragment in a randomly cut rock for a sedimentological analysis suggests a relatively high abundance.

Here we present preliminary results on the ootaxonomic diversity of El Horcajo, a microvertebrate site in palustrine facies of the Enciso Group, located in the surroundings of the locality of Trevijano (La Rioja). This is the first eggshell site discovered in the Lower Cretaceous of the Cameros Basin, and one of the oldest eggshell localities of Spain. a un nuevo oogénero y ooespecie; 3) Krokolithes sp. de la oofamilia Krokolithidae; 4) cáscaras recristalizadas asignables con dudas a Testudoolithidae; y 5) cáscaras de afinidad incierta, aquí asignadas con dudas a Geckoolithidae. Esta oodiversidad es similar a la de otros microyacimientos de cáscaras de huevo. La lista ootaxonómica difiere de la obtenida en la otra única localidad de esta edad en Iberia, Pochancalo 1 (Formación Villanueva de Huerva, Zaragoza), por la ausencia de cáscaras de huevo asignables a saurópodos y terópodos megalosauroideos, pero comparte la presencia de cáscaras de huevo asignables a ornitópodos y terópodos celurosaurios con otros yacimientos más recientes que muestran facies similares. Este nuevo yacimiento tiene consecuencias inmediatas para el marco tectono-sedimentario de la cuenca de Cameros, siendo necesario considerar estos nuevos datos en futuros estudios estratigráficos. Además, se cuestiona la fiabilidad del uso de cáscaras de huevo como marcadores bioestratigráficos, ya que los nuevos datos ponen en duda la utilidad de Guegoolithus como fósil guía para el Barremiense inferior.

Palabras clave. Valanginiense-Hauteriviense, Grupo Enciso, cáscaras de huevo de vertebrados, dinosaurios.

\section{MATERIAL AND METHODS}

The El Horcajo site was found by one of us (A.F.) during a survey for footprints in the late nineties of the past century. Several eggshell fragments were collected in successive visits to the locality. Approximately one hundred of kilograms of sediments from the El Horcajo site were collected in two points where eggshell fragments were visible with the naked eye. The samples, labeled as "Trevijano clásico" (classical, TRE) for the previously known locality and "Trevijano nuevo" (new, TREN), showed no differences in eggshell size, diversity and abundance, so they were treated as a single sample. Sediment was let dry for a couple of weeks and them were processed using $2 \%$ hydrogen peroxide and sieves of 2 $\mathrm{mm}, 1 \mathrm{~mm}$ and $0.5 \mathrm{~mm}$ mesh. The eggshell fragments were sorted under a binocular microscope. Some of the fragments where prepared in standard $30 \mu \mathrm{m}$ thin section in radial view. Noticeable is the bad results obtained in thin sections of eggshell fragments of under $500 \mu \mathrm{m}$ in thickness. Thin sections were examined with an Olympus BX 41 petrographic microscope housed in the Mineralogy and Crystallographic area of Earth Sciences Department of the University of Zaragoza. Forty-four fragments where mounted for Scanning Electron Microscopy (SEM) and gold coated. In addition, twenty-three fructifications of charophytes were randomly picked up from the $0.5 \mathrm{~mm}$ mesh fraction and mounted and gold coated for SEM analysis. They were examined in a JEOL 6400 SEM 
housed in the "Servicio de Microscopía Electrónica de Materiales" of the University of Zaragoza.

All materials were collected under the local regulations and are housed in the Museo de Enciso (Enciso, La Rioja).

Nomenclature follows the works of Mikhailov (1991, 1997) and Mikhailov et al. (1996), with the exception of Krokolithidae eggshells, which follows Moreno-Azanza et al. (2014a).
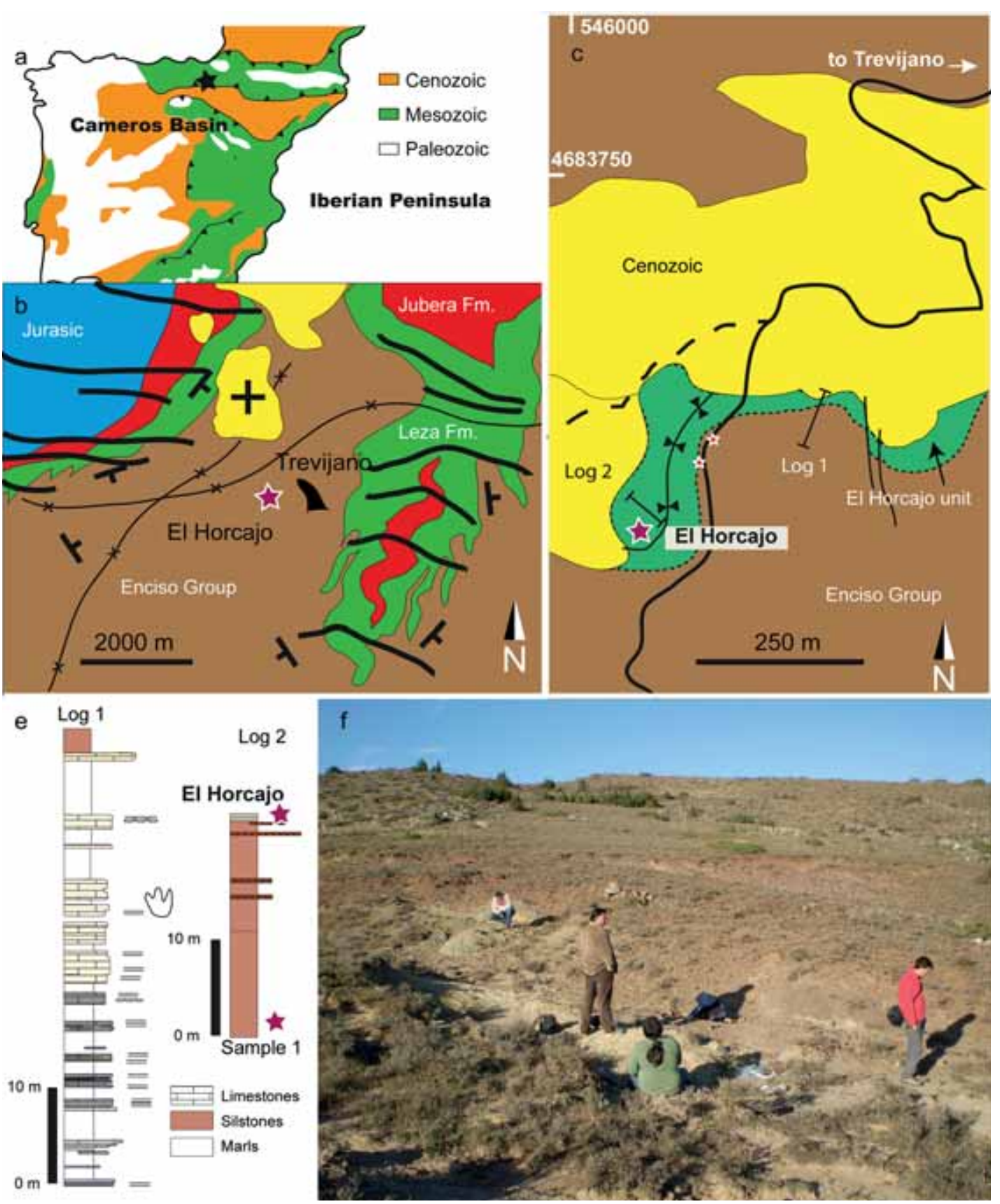

Figure 1. Geographical and geological location of the El Horcajo site (La Rioja). a) Location of the Cameros Basin within the

Iberian Peninsula. b) Geological context of El Horcajo. Based on Suárez-González et al. (2013). c) Detailed geological
mapping of the El Horcajo area, showing the location of the site and the two stratigraphic logs. d) Stratigraphic logs of
the El Horcajo area, showing the location of the El Horcajo and the Sample 1 (see text). e) View of the El Horcajo site

Iberian Peninsula. b) Geological context of El Horcajo. Based on Suárez-González et al. (2013). c) Detailed geological
mapping of the El Horcajo area, showing the location of the site and the two stratigraphic logs. d) Stratigraphic logs of
the El Horcajo area, showing the location of the El Horcajo and the Sample 1 (see text). e) View of the El Horcajo site

Iberian Peninsula. b) Geological context of El Horcajo. Based on Suárez-González et al. (2013). c) Detailed geological
mapping of the El Horcajo area, showing the location of the site and the two stratigraphic logs. d) Stratigraphic logs of
the El Horcajo area, showing the location of the El Horcajo and the Sample 1 (see text). e) View of the El Horcajo site during the survey works in 2008.

\section{GEOGRAPHICAL AND GEOLOGICAL SETTING}

The El Horcajo site is located one kilometer west to the village of Trevijano (La Rioja, north of Spain; Figs 1a-1c).

The Cameros Basin originated during the end of the Jurassic due to an intraplate rifting event associated to the opening of the North Atlantic, lasting until the middle Albian. It was an accelerated subsidence cycle, resulting 
in over $6500 \mathrm{~m}$ of mainly continental sediments (Mas et al., 1993; Salas et al., 2001; Omodeo-Salè et al., 2014), and was characterized by a low temperature metamorphism (Omodeo-Salè et al., 2015 and references within). Four lithoestratigraphic units have been recognized in the area: Tera Group, Oncala Group, Enciso Group and Olivan Group (Tischer, 1966). At least the Oncala and Enciso Group show certain marine influences (Schudack \& Schudack, 2009; Mas et al., 2004; Quijada et al., 2013; Suárez-González et al., 2010, 2015).

The El Horcajo level consists of grey marls included in a red clay-grey marl interval (Figs 1d-1e) that was deposited in a lacustrine-palustrine environment, with coastal influence, overlaying the Enciso Group limestones. The outcrop is small; it is directly overlaid by a postcompression Cenozoic poorly-sorted breccia.

The fossil assemblage of El Horcajo comprises charophytes, ostracods and vertebrate remains including abundant eggshell fragments, ornithopod and theropod dinosaur teeth, an ornithopod vertebra, crocodylomorph teeth (Bernissartia and atoposaurids), as well as scales and teeth of osteichthyan fishes.

The outcrops of the El Horcajo site have been mapped and assigned to the Enciso Group (Suárez-
González et al., 2013). In any case, it should be noted the controversy concerning the stratigraphic position and age of the sedimentary succession from Trevijano area (see a comparative overview of different proposals for the units of the northernmost area of the Cameros Basin in Suárez-González et al., 2013; fig. 5). Previous works showed different interpretations identifying the unit that contains El Horcajo site as either Enciso Group or Oncala Group, and its age ranges between Berriasian to early Aptian (e.g. Doublet, 2004; Schudack \& Schudack, 2009; Suárez-González et al., 2013). The discussion about formal stratigraphic units requires further fieldwork and is out of the scopes of this work, but we provide new data concerning the age based on the fossil content of the studied site.

\subsection{Age}

The assemblage of charophyte fructifications identified in the El Horcajo site is composed of a mixed population of two successive anagenetic varieties: Atopochara trivolvis micranda and Atapochara trivolvis ancora (Fig. 2). Specimens belonging to the more primitive Atopochara

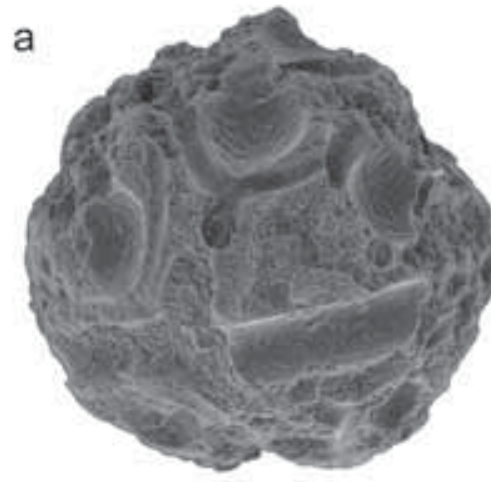

b
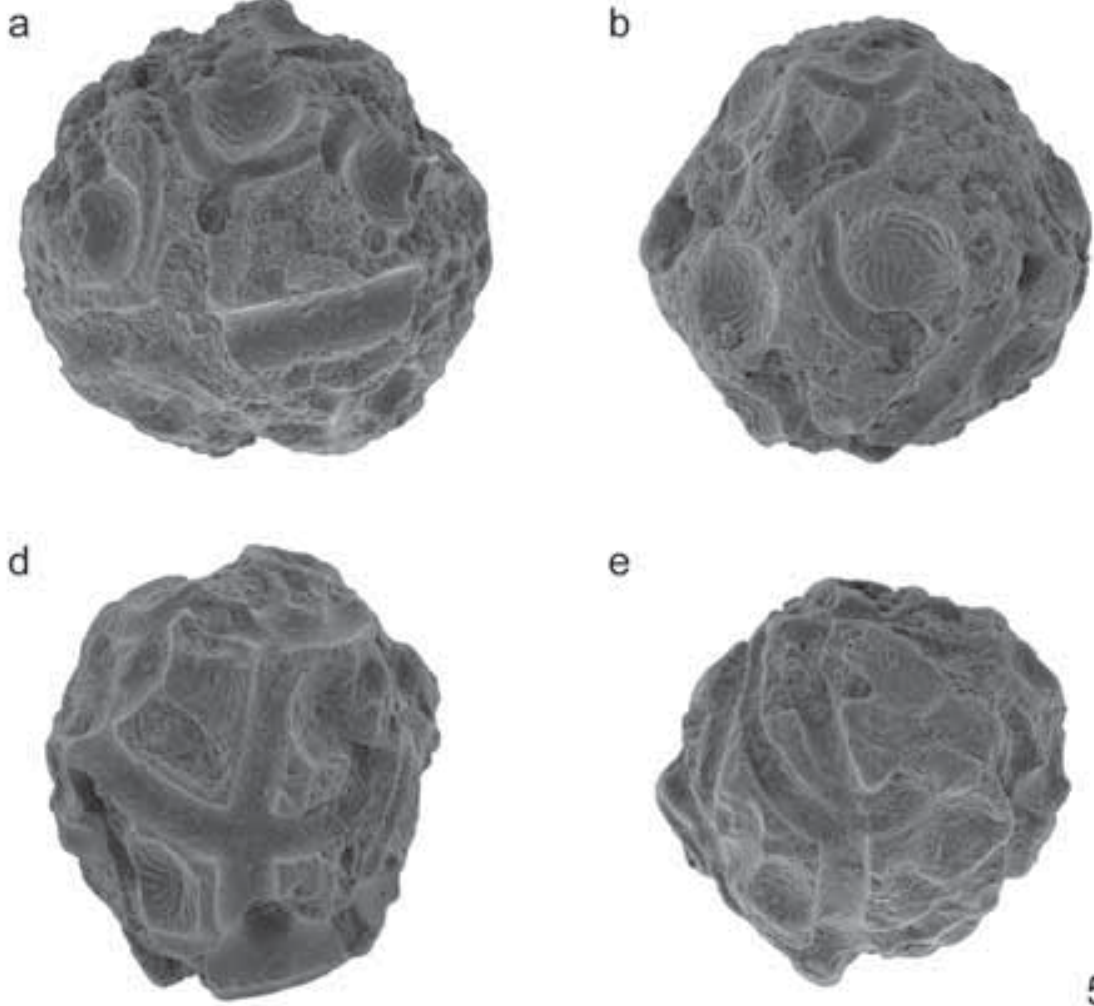

e

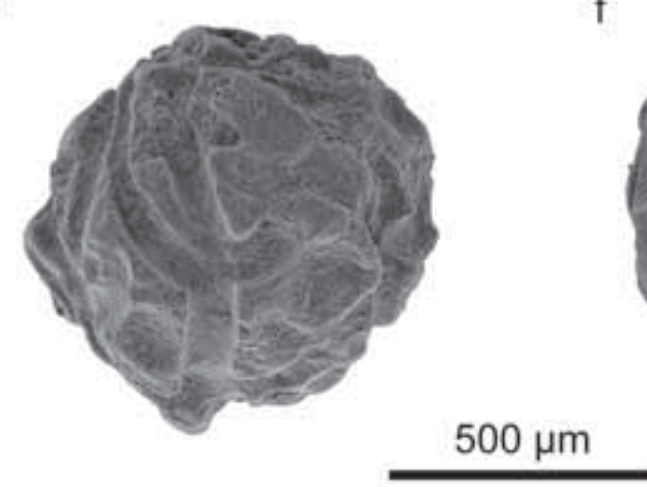

f
C
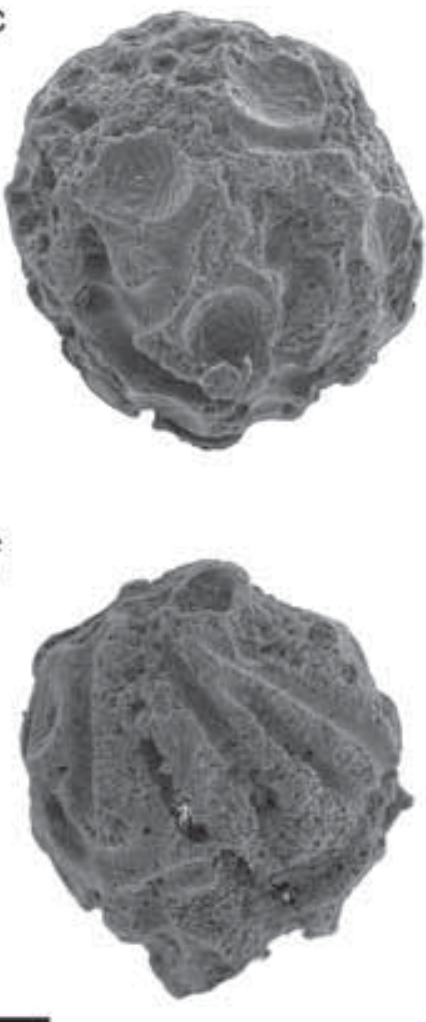

Figure 2. Charophyte fructifications from the Trevijano fossil site (La Rioja), in roughly lateral view. (a-c) Atopochara trivolvis var. micranda and (d-f) Atopochara trivolvis var. ancora, sample Trevijano. a) Menc-Tre_36. b) Menc-Tre_33. c) MENCTRE 37. d) MENC-TRE 26. e) MENC-TRE 30. f) MENC-TRE 28. 
trivolvis micranda are between $800-950 \mu \mathrm{m}$ in diameter and bear antheridial marks $180-220 \mu \mathrm{m}$ in diameter. Specimens of Atopochara trivolvis ancora are minor in number and slightly smaller than that of the former variety, being $750-850 \mu \mathrm{m}$ in diameter with antheridial marks between 140-200 $\mu \mathrm{m}$. These ranges are coherent with those described for these varieties in other places (MartínClosas, 2000). This assemblage indicates a ValanginianHauterivian age for the fossiliferous level being within the Globator maillardii steinhauseri zone of Riveline et al. (1996). This dating is in agreement with the ostracod biostratigraphy proposed by Schudack \& Schudack (2009) but not with data based on Dasycladaceae algae provided by Suárez-González et al. (2013). As additional data for the biostratigraphy of the unit, it is appropriate to note the presence of the charophyte Globator maillardii nurrensis within the local series, in a sample located $25 \mathrm{~m}$ below the El Horcajo site. Therefore, the lower part of this unit would be late Berriasian in age (Globator maillardii nurrensis biozone; Riveline et al., 1996).

\section{SYSTEMATIC PALAEONTOLOGY}

Parasystem VETEROVATA Vyalov, 1972

Oofamily Spheroolithidae Zhao, 1979

Oogenus Guegoolithus Moreno-Azanza, Gasca \& Canudo, 2014c

Oospecies Guegoolithus turolensis (Amo Sanjuan, Canudo \& Cuenca Bescós, 2000)

(Fig. 3)

Description. Eggshell fragments assigned to Guegoolithus are dark brown to black in color. They show evidence of weathering in both inner and outer surfaces (Fig. 3a), although the ultrastructure of the eggshell is pristine preserved. The eggshell is $1100 \mu \mathrm{m}$ thick. They have prolatospherulithic shell units that completely fuse at one fifth to one third of the thickness of the eggshell (Fig. 3b). Shell units form a single layer of radiating calcite crystals. This layer shows a progressive change in ultrastructure, from spherulithes of acicular ultrastructure (Fig. 3c), formed by thin acicular crystals of calcite that radiate out of the organic cores. These acicular crystals progressively develop into wedges with radial tabular ultrastructure (Fig. 3d). The relation between the acicular and the radial tabular "layers" is $3: 1$.

This pseudo-layered condition is also evident in thin section (Fig. 3e). In the lower third of the eggshell, the shell units are not fused and show no lamination. The two upper thirds of the eggshell, on the contrary, display a strong lamination, with growth lines that are continuous across the shell unit boundaries. The lower growth lines are straight to slightly wavy, but they progressively increase in undulation towards the outer surface, becoming subparallel to the ornamentation in the outer part of the eggshell. The eggshell displays undulating extinction (Fig. 3f). Pore channels are prolatocanaliculated.

The outer surfaces present sagenotuberculated ornamentation (Fig. 3a). The anastomosing ridges leave deep valleys in their interstices. An isolated fragment, otherwise being identical to those fragments here assigned to Guegoolithus, shows compactituberculated ornamentation, although this can be an artifact due to the small size of the fragment. The ornamentation comprises up to one fourth of the eggshell thickness (Fig. 3b), with deference of thickness between ridges and valleys of up to $250 \mu \mathrm{m}$, but this value may be an underestimation, due to the weathering shown in most of the examined eggshell fragments.

Comparison. The prolaspherulithic eggshell, with prolatocanaliculated pore system, together with the sagenotuberculated ornamentation allows the inclusion of these eggshells in Spheroolithidae. This oofamily includes three valid oogenera: Shixingoolithus, Spheroolithus and Guegoolithus (Barta et al., 2014; Moreno-Azanza et al., 2014c). The Spheroolithidae eggshells from El Horcajo are two times thinner than those assigned to Shixingoolithus. They have a similar thickness than most of Spheroolithus eggshells (see table 1 in Moreno-Azanza et al. (2014c), but also Tanaka et al., (2016) for an exceptional thin Spheroolithus oosp.). The prominent sagenotuberculated ornamentation observed in the El Horcajo Spheroolithidae eggshells is not shared with any Spheroolithus oospecies. Furthermore, the eggshell thickness, the presence of spherulithes with acicular ultrastructure that progressively develop into tabular ultrastructure and the prominent ornamentation of the outer surface is shared with the oogenus Guegoolithus, and with the only included oospecies, Guegoolithus turolensis.

Eggshells of Guegoolithus have been recovered in many localities of the neighboring Iberian Basin, but its presence is restricted to the Lower Barremian (Canudo et al., 2010; Moreno-Azanza et al., 2014c). If the Hauterivian-Valanginian age of El Horcajo is confirmed, it would imply that these eggs where laid in the Iberian Peninsula up to seven million years before than previously thought (see the Discussion section).

Guegoolithus has been tentatively related to iguanodontoid dinosaurs on the basis of their resemblance to eggshells assigned to derived ornithopods from the Upper Cretaceous of North America (Horner \& Makela, 1979; Hirsch \& Quinn, 1990; Horner, 1999) and, more recently, from the Lower Cretaceous of Asia (Dewaele et al., 2015). 


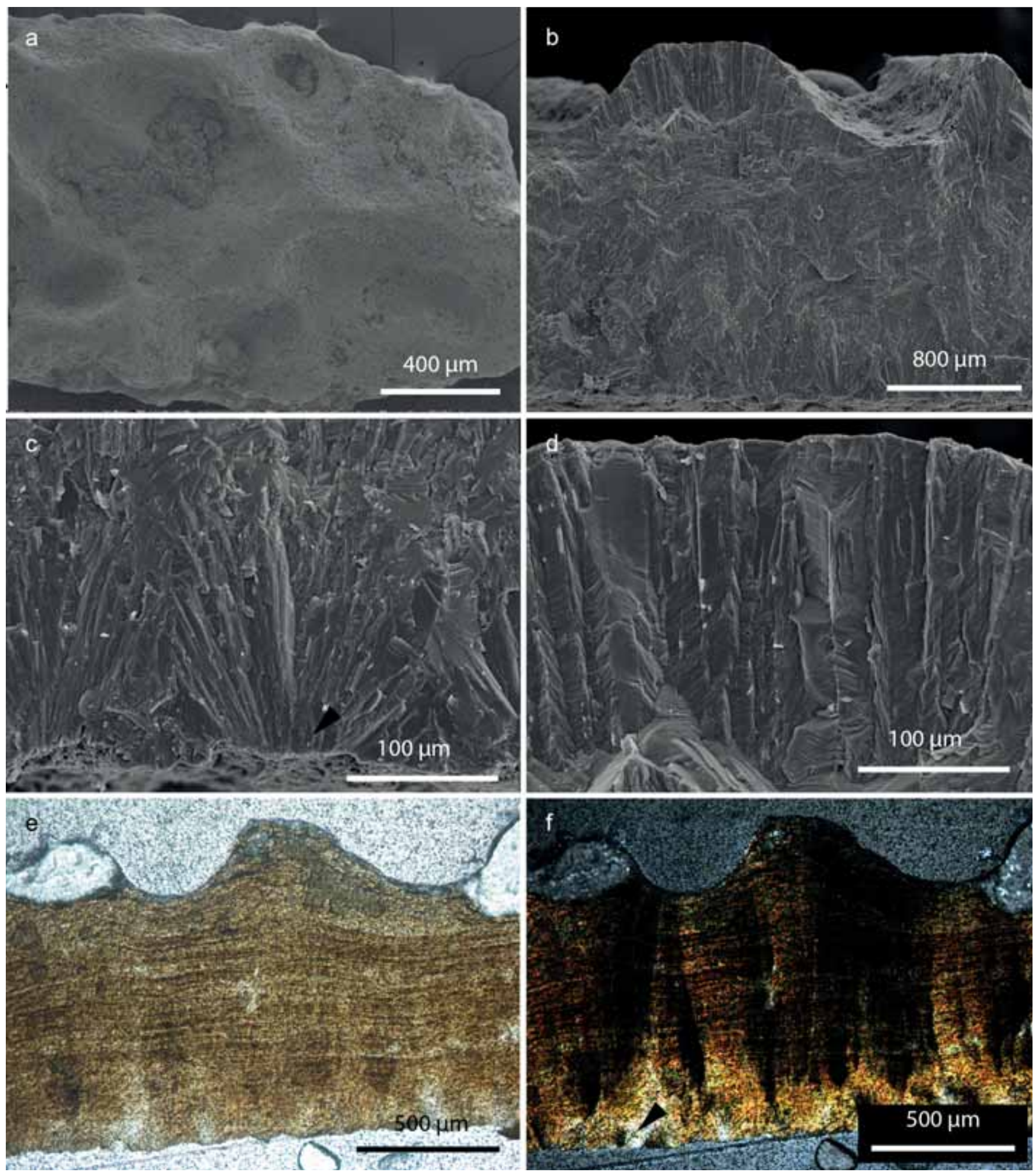

Figure 3. Guegoolithus turolensis from the El Horcajo site (La Rioja). Scanning electron microscope microphotographs (a-d), petrographic microscope photograph in parallel nicols (e), and petrographic microscope photograph in cross nicols (f). a) MENC- MENC-TREN-13. Outer surface showing sagenotuberculated ornamentation. b) TRE-2. Radial section of the eggshell. c) MENC-TRE-2. Detail of the mammillae showed in a. Note the radial acicular ultrastructure. Black arrowhead points a preserved organic core. d) MENC-TRE-2. Detail of the upper part of the eggshell, showing radial tabular ultrastructure. e) MENC-TREH1. Above the mammillae, the eggshell shows an intense lamination, parallel at the bottom and progressively undulating to the top. f) MENC-TREH1. Observe the undulating extinction. Black arrowhead points a preserved organic core. 
Oofamily Prismatoolithidae Hirsch, 1994 emend. Moreno-Azanza et al., 2014b.

\section{Oogenus et oospecies indet.} (Fig. 4)

Description. Eggshells assigned to Prismatoolithidae indet. are the thickest of the El Horcajo assemblage. They are black in color and are easily identified due to its lack of ornamentation. Eggshell fragments of this type are usually bigger than the others, and can be picked in the field with the naked eye. The eggshell fragments show evidence of weathering, most probably due to a significant transport from the nesting area to the assemblage (Fig. 4a).

Eggshell fragments are $1400 \mu \mathrm{m}$ thick on average. The shell unit is formed by a palisade of columnar prisms with a height/width ratio of 4:1 (Fig. 4b). The eggshell presents two layers, a mammillary layer and a prismatic layer with a gradual transition between the two layers. The ratio between the mammillary layer and the prismatic layer is 1:4. The mammillary layer comprises one fifth of the eggshell. It presents a massive appearance in the SEM, and no organic cores can be observed (Fig. 4c). The prismatic layer has a radial tabular ultrastructure (Fig. 4d). Two different zones of similar thickness can be distinguished in this layer (Fig. 4b). The inner zone looks somewhat massive in SEM photographs, but some crystals wedges can be identified, and calcite lattice can be distinguished in some areas. The outer zone has a better preserved structure, with parallel columns of calcite forming a tight palisade in each prism, and display the typical radial tabular ultrastructure, with a well-developed fish bone pattern produced by the lattice of the calcite (Fig. 4d). No evidence of true squamatic structure is observed in the prismatic layer.

In thin section, the eggshell is light colored (Fig. 4e). The bases of the prisms present a dark brown color in parallel nicols, and no clear pattern of extinction in cross nicols, suggesting that these areas of the eggshell are fine grained and rich in organic matter. There is a faint lamination, formed by light brown growth lines that are restricted to each shell unit. It is possible that the original structure of the eggshell is here masked by recrystallization or a high abundance of organic matter. Nevertheless, shadows of former organic cores can be observed. The prismatic layer shows no lamination. The inner zone of this layer has a general darker color, and this may be due to the presence of degraded organic matter. In cross-polarized light (Fig. 4f), crystalline domains are here small and elongated, and have an inclination with respect to the eggshell growth direction, fanning out from the mammillary layer. They have columnar extinction pattern. The outer zone of the prismatic layer is again light coloured, with less relicts of organic matter. Here, crystalline domains are noticeably larger, are almost parallel to the eggshell growth direction, and also present columnar extinction.

Comparison. The multilayered condition of the eggshell, together with a mammillary layer and a prismatic layer separated by a gradual transition and with the radial tabular ultrastructure present in the prismatic layer are diagnostic characters of the oofamily Prismatoolithidae. Nevertheless, it is thicker than any other oospecies of this oofamily. This oofamily includes several oogenera eggs with smooth, undulating and sculptured outer surfaces. The prismatoolithids of El Horcajo are twice as thick than any other two layered, smooth Prismatoolithidae oogenera (maximum thickness of $1400 \mu \mathrm{m}$ ). Its thickness is only similar to eggs assigned to the oogenus Trigonoolithus, from the lower Barremian of Spain (maximum thickness of $1200 \mu \mathrm{m}$; Moreno-Azanza et al., 2014b), and to the Upper Cretaceous Prismatoolithus levis/Troodon formosus (maximum thickness of $1200 \mu \mathrm{m}$; Zelenitsky \& Hills, 1996). Furthermore, a third structural layer, the outer layer, has been described for both ootaxa.

The presence of a third layer in the Prismatoolithidae eggshells of El Horcajo is worth of discussion. There is a clear ultrastructural difference between the inner and outer zones of the prismatic layer. This condition has been described in the Prismatoolithidae oospecies Sankofa pyrenaica, from the Upper Cretaceous of Spain (LópezMartínez \& Vicens, 2012). Sankofa shows an even more strong differentiation between the "internal and external" zones of the prismatic layer. This contrast is most noticeable in thin sections, where Sankofa shows a diagnostic jagged shape of the extinction domains. This condition is less pronounced in the El Horcajo Prismatoolithidae indet. López-Martínez \& Vicens (2012) did not consider this change in the ultrastructure of the eggshell worth of distinguishing two layers, and we have chosen to follow their recommendations. Even if a third layer is recognised, this layer is much thicker, both absolutely and in relation with the mammillary and prismatic layer than in any other Prismatoolithidae, including Trigonoolithus and Prismatoolithus levis/Troodon formosus. Prismatoolithidae indet. from El Horcajo differs from Sankofa pyrenaica in having a much thicker eggshell, wither prisms, less developed jagged crystalline domains and in the lack of squamatic ultrastructure in the prismatic layer, even though this absence can be an artifact resulting from fossilization (Mikhailov, 2014). It is possible that these eggshells represent a new oospecies of Prismatoolithidae, either belonging or not to the oogenus Sankofa, but more material is needed to erect this new ootaxon.

Prismatoolithid eggshells have been described in several groups of derived theropods, including birds and troodontids (Horner \& Weishampel, 1996; Varricchio et al., 1997), and in some basal theropods, such as Lourinhanosaurus (Mateus et al., 1997). Tanaka et al. 


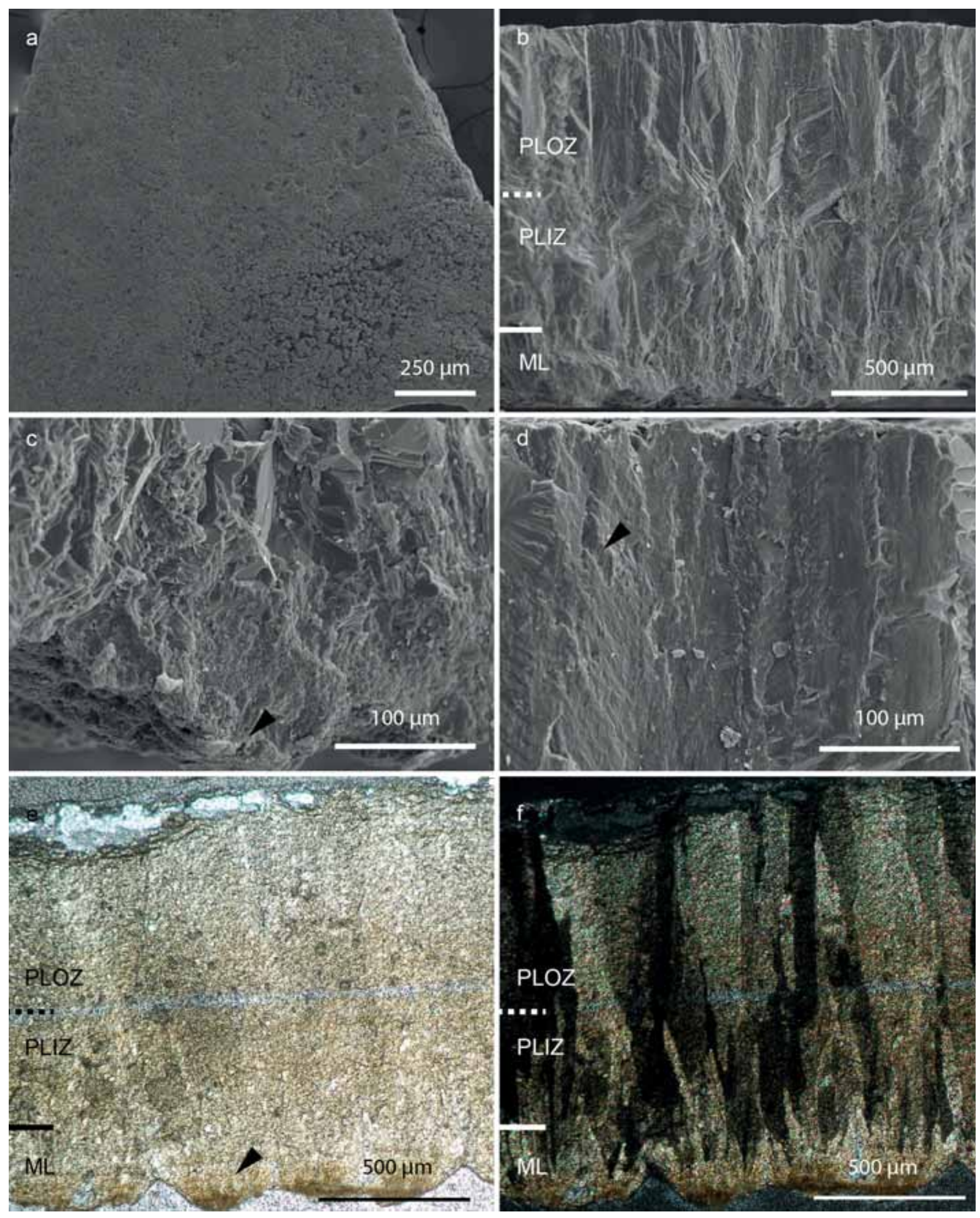


(2016) found a direct relation between eggshell thickness and egg mass, resulting of an egg mass of over half a kilogram for the Prismatoolithidae indet. from El Horcajo. Thus, Prismatoolithidae eggs from El Horcajo were most probably laid by a medium to big sized theropod.

\section{Oofamily Krokolithidae Köhring \& Hirsch, 1996 Oogenus Krokolithes Hirsch, 1985}

\section{Krokolithes oosp.}

(Fig. 5)

Description. Small brown to black eggshell fragments. The outer surface presents rugosocavate ornamentation (sensu Marzola et al., 2015), with low and wide bumps that irregularly cover the eggshell surface (Fig. 5a). Dissolution pits are scarce and are not present in all eggshell fragments. They are sub-circular and present the characteristic concentric rings of the crocodile eggshell (Fig. 5b).

Eggshell is $333 \mu \mathrm{m}$ thick on average. Eggshell units are wide, with a width to height ratio of 0.6 (Fig. $5 \mathrm{c}$ ). The shell units are discrete, although they somewhat fuse at one half of the eggshell. These units are trapezoidal in shape, with small interstices between the bases of adjacent units. The eggshell has three structural layers: a thin (30 $\mu \mathrm{m})$ lower layer, comprising small globular basal knobs, of $60 \mu \mathrm{m}$ in diameter; a middle layer, densely calcified but showing shadows of a compact tabular ultrastructure; and an external layer, with a more fibrous structure. The ratio between the thickness of these layers is $1 / 5 / 5$. In the lower layer (Fig. 5d), basal knobs centers are loosely spaced and are located at the bases of the shell units. They are massive, with no clear crystallographic structure. The middle layer is more compact in structure and relicts of the tabular ultrastructure, orthogonal to the eggshell growth direction, can be seen (Fig. 5d). The external layer has a fibrous aspect, with a parallel cleavage in an angle to the eggshell surface (Fig. 5e).
No good quality thin sections were obtained from these eggshells, due to is brittle structure and small thickness. Nevertheless, they showed blocky extinction in cross nicols (Fig. 5f).

Comparison. The three layers present in the eggshell, the presence of basal knobs, the tabular structure of the middle layer, the blocky extinction and the presence of extrinsic dissolution pits are all common features of Krokolithidae eggshells, also shared by extant crocodiles. This oofamily is pending of a deep revision, currently only two oogenera, Krokolithes (Hirsch, 1985) and Bauruoolithus (Oliveira et al., 2011) have been defined, with most eggshells described for this oofamily regarded as crocodile eggshell or referred to Krokolithes without further discussion (see Moreno-Azanza et al., 2014a). The eggshells from El Horcajo are three layered and a $50 \%$ thicker than those assigned to the single layered Bauruoolithus. The eggshells from El Horcajo are thin for most Cretaceous Krokolithes, with the exception of the 300- $\mu \mathrm{m}$-thick Krokolithes oosp. from La Cantalera in Galve, Teruel (Canudo et al., 2010). Nevertheless, Krokolithes oosp. from La Cantalera presents wider shell units. On the other hand, the Krokolithidae eggshells from El Horcajo are similar to those of Krokolithes helleri from the Lutetian of Germany (Köhring \& Hirsch, 1996), although the most diagnostic feature of this oospecies, the well-developed basal plate group, is not preserved in the eggshells of El Horcajo. Thus, we choose to assign them to Krokolithes oosp.

\section{Oofamily ?Testudoolithidae Hirsch, 1996}

Oogenus et oospecies indet. (Fig. 6a)

Description. Eggshells of this type are thin $(330 \mu \mathrm{m})$. The eggshell is single layered, with wide cylindrical shell

Figure 4. Prismatoolithidae indet. from the El Horcajo site (La Rioja). Scanning electron microscope microphotographs (a-d), petrographic microscope photograph in parallel nicols (e), and petrographic microscope photograph in cross nicols (f). a) MENC- MENC-TREN-1. Smooth outer surface of the eggshell. Note the important degree of weathering shown in the bottom right of the picture, with partial dissolution of the eggshell surface. b) MENC-TRE-3. Radial section of the eggshell. Note the gradual transition between the mammillary layer and the prismatic layer, and the change in the orientation of the crystals in the middle of the prismatic layer. c) MENC-TRE-3. Detail of the mammillary layer in Fig. 4a. Note the massive aspect of the layer, specifically in the bottom of the picture, were individual crystals can hardly be seen. Black arrowhead points an organic core. d) MENC-TRE-3. Detail of the upper part of the prismatic layer in Fig. 4a. Arrowhead points the tabular ultrastructure of the prisms. e) MENC-TREH3. Radial thin section of the eggshell. Note the progressive transition between the mammillary and prismatic layers, and the increase in organic matter in the inner zone of the prismatic layer. Black arrowhead points a dark brown shadow at the bases of the mammillae, which may also represent enrichment in organic matter associated to the presence of the organic core. f) MENC-TRE H3. The eggshell shows columnar extinction. Cross polarized light allows to easily spotting the limit between the mammillary and prismatic layers. Note the increase of size of the extinction domains and their change in orientation, from divergent to parallel, in the transition between the inner and outer zones of the prismatic layer. ML: mammillary layer. PLIZ: Inner zone of the prismatic layer. PLOZ: Outer zone of the prismatic layer. 

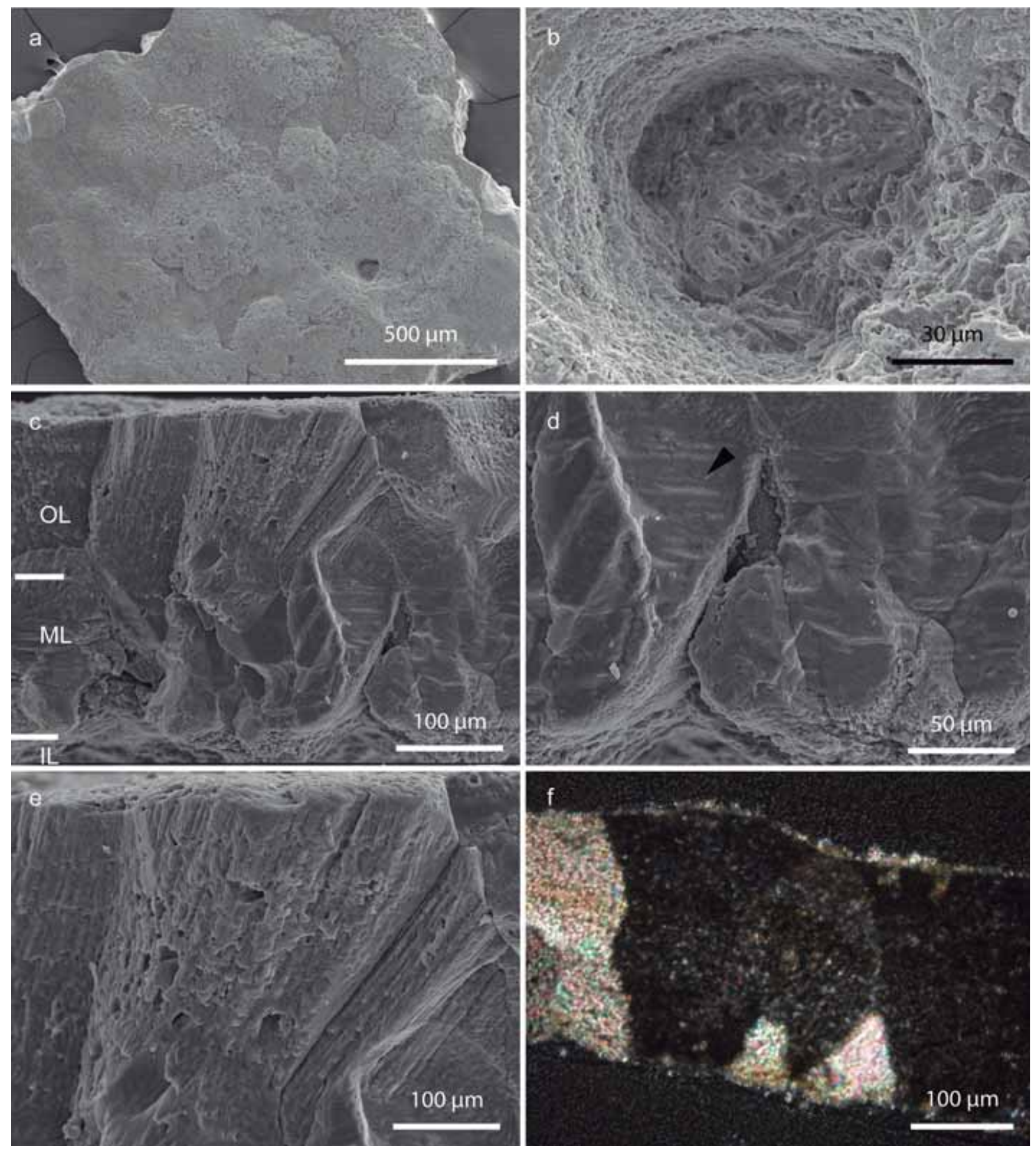

Figure 5. Krokolithes sp. from the El Horcajo site (La Rioja). Scanning electron microscope microphotographs (a-e), and petrographic microscope photograph in cross nicols (f). a) MENC-TREN-7. Outer surface of the eggshell, showing small bumps and dissolution pits, forming the rugosocavate ornamentation. b) MENC-TREN-7. Detail of a dissolution pit, probably a rounded pore opening exaggerated by extrinsic degradation. Note the dissolution rings. c) MENC-TRE-9. Radial thin section showing the relations of the inner, middle and outer layers. Note the trapezoidal shape of the shell units. d) MENC-TRE_9. Detail of the inner and middle layers of the eggshell in Fig. 5a. Note the basal knob in the inner layer and the absence of the petal like structure of the basal group. Black arrowhead marks the book like tabular ultrastructure of the wedges, characteristic of the crocodilian eggshell. e) TRE-9. Detail of the outer layer in a. Note the fibrous aspect of the layer, due to the lattice plains of the calcite. This layer shows abundant vesicles. f) MENC-TRE_N9_3. The eggshell has blocky extinction. IL: inner layer. ML: middle layer. OL: outer layer. 
units (width to height ratio of 1:1). The eggshell shows a radial ultrastructure, with calcite acicular crystals that radiate out of an organic core (Fig. 6a). In some areas, these acicular crystals are replaced by large euhedral calcite crystals, with rhombohedral habit, showing the typical calcite angles ( 72 to $75^{\circ}$, as measured in SEM photographs). Both acicular and rhombohedral crystals show many small "vesicles", probably relicts of organic matter. No organic cores are present, but big erosion craters (over $100 \mu \mathrm{m}$ in diameter) can be seen in the inner surfaces. The outer surfaces are smooth.

Comparison. Single layered eggshells with radial calcite ultrastructure are present in both Spheroolithidae and Megaloolithidae (Mikhailov, 1991, 1997), two oofamilies related to ornithopod and sauropod dinosaurs (Horner \& Makela, 1979; Calvo et al., 1997). Nevertheless, neither of these oofamilies shows shell units as wide as tall, as it is the case of the eggshells of El Horcajo. The presence of euhedral rhombohedral crystals of calcite suggests that the eggshell may be recrystallized. This contrasts with the pristine appearance of all eggshells recovered in El Horcajo site, where the ultrastructure of the eggshells has been preserved to the minimal detail, even when evidences of transport exists (Fig. 6a). Turtle eggshells are the only eggshells that are made of aragonite instead of calcite, a less stable mineral form of calcium carbonate. Aragonite usually recrystallizes to calcite in standard fossilization conditions, moreover in the presence of a regional hydrotermal metamorphism as the one that the Cameros Basin went through.

Rigid turtle eggshells with a width/height ratio of 1:1 are common in the oofamily Testudoolithidae. The poorly preserved ultrastructure and the lack of good thin sections preclude an in-depth discussion of the systematic classification of the eggshell.

\section{Oofamily ?Geckoolithidae Hirsch, 1996}

(Fig. 6b)
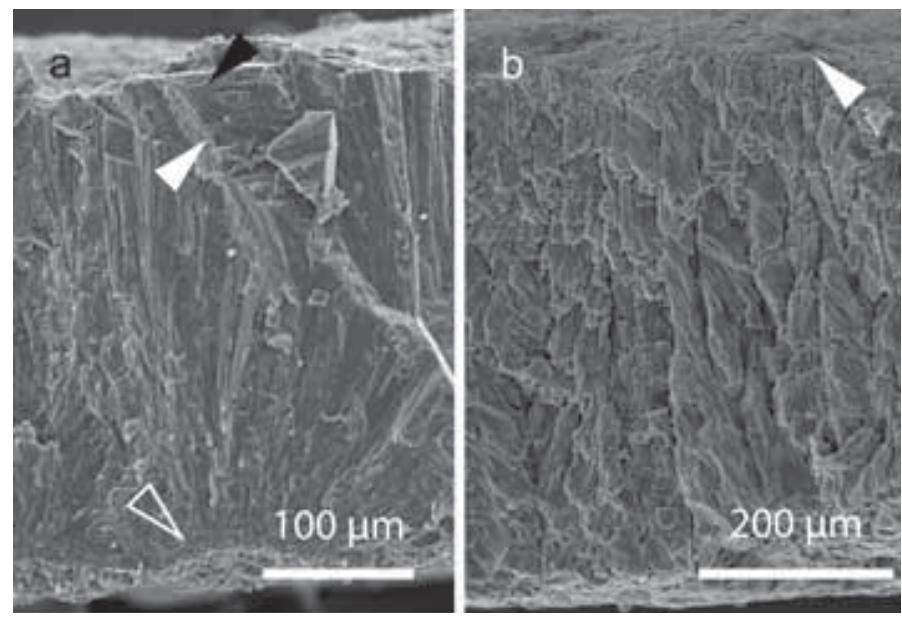

Description. Eggshell fragments here regarded as ?Geckoolithidae indet. are thin $(500 \mu \mathrm{m})$ single layered calcite eggshells. No shell units can be distinguished. Instead, the eggshell is composed of a palisade of elongated crystals, with a diameter of 30-40 $\mu \mathrm{m}$ and a length of 500 $\mu \mathrm{m}$. The crystals do not appear to fan out from the bottom of the eggshell. Instead, they are completely parallel, from the bottom to the top of the eggshell. These are neither acicular crystals, as seen in spheroolithid eggshells, nor prisms, as seen on prismatoolithid eggshells. These crystals are somewhat irregular and branching to an extent, giving the eggshell a flaming aspect. The outer surface is smooth at the naked-eye scale, but dispersituberculate in the SEM photographs. There are small bumps in the outer surface. They have $50 \mu \mathrm{m}$ in diameter and are massive, with no discernable structure.

Comparison. Single layered eggshells have been described in the eggs of extant geckos, such as Gecko gecko and Phelsuma madagascariensis. The fossil oogenus Geckoolithus (Hirsch, 1996), although described as single layered, presents two distinct layers: a thick, densely calcified inner layer, and a more fibrous upper layer. The general architecture of the eggshell is similar to that of the extant geckos eggs, which also consists in tight palisades of prismatic crystals. Nevertheless, El Horcajo eggshells are much thicker than any extant or fossil gecko eggshells. Two Geckoolithidae ootaxa have being described in Spain. Köhring (1991) described gecko eggshells from the late Barremian of Uña (Cuenca). This eggshells are twice thinner than the ?Geckoolithidae from El Horcajo, and present a more massive prismatic layer. Furthermore, the surface nodes of the Uña eggshells are twice as big. Another ootaxa, Pseudogeckoolithus, was first described as resembling the structure of Geckoolithus, but being a prismatoolithid eggshell laid by a theropod dinosaur (Vianey-Liaud \& López-Martínez, 1997). Recently, Sellés (2012) examined a new and wider sample

Figure 6. a) MENC-TRE 5. ?Testudoolithidae indet. from the El Horcajo site (La Rioja). Scanning electron microscope photograph of the radial section of the eggshell. The eggshell presents cylindrical shell units, with a width/height ratio of 1:1. The ultrastructure is radial. Hollow arrowhead points an erosion crater, relict of an eroded organic core. White arrowhead points vesicles, observed in the whole eggshell. Black arrowhead points an euhedral calcite crystal, showing typical calcite exfoliation angles of $74^{\circ} 55^{\prime}$. This crystal suggests that the whole eggshell is recrystallized. b) MENC-TRE-11. ?Geckoolithidae indet. from the El Horcajo site (La Rioja). The eggshell is single layered, with the only layer consisting of a tight palisade of elongated calcite crystals, with a flaming aspect. White arrowhead points a node in the outer surface. 
of eggshell fragments and confirmed its Geckoolithidae affinities. El Horcajo ?Geckoolithidae indet. differs from Pseudogeckoolithus in having a thicker eggshell and lacking pore openings on top of the outer surface nodes.

\section{DISCUSSION}

The El Horcajo site has yielded a diverse ootaxa assemblage with at least five recognized ootaxa despite the low mass of sediment processed. This diversity is high when compared with traditional egg localities, but recent studies, especially those based on fossils collected by washing and sieving sediment (e.g. Buscalioni et al., 2008; Canudo et al., 2010; Tanaka et al., 2016), are uncovering a previously unnoticed eggshell diversity, at least in the Lower Cretaceous deposits all over the world.
El Horcajo site has provided the oldest fossil eggshells of Spain. Only Pochancalo 1, in the Villanueva de Huerva Formation of Zaragoza, has a similar age (VallanginianHauterivian; Gasca et al., 2012). Interestingly, the ootaxa association of Pochancalo 1 presents differences with the ootaxa association of El Horcajo (Table 1) (see MorenoAzanza, 2014 for an updated ootaxonomic list of Pochancalo 1). Both localities share the presence of Krokolithidae and Testudoolithidae ootaxa. Nevertheless, Krokolithes has proven to be an omnipresent oogenus in most of the Lower Cretaceous localities of Spain, and Testudoolithidae eggshells found in both localities are highly recrystallized, which precludes comparison. Important differences arisen when comparing the dinosaurian eggshell assemblage of both localities. Pochancalo 1 has provided Megaloolithidae eggshells, assigned to sauropod dinosaurs on the base of embryonic remains from the Late Cretaceous of Argentina (Chiappe et al., 1998), and Phaceloolithidae eggshells, assigned to Torvosaurus, a megalosauroid theropod

Table 1. Comparasion between the ootaxa associations of contemporaneous sites Pochancalo 1 (Villanueva de Hueva, Zaragoza) (Moreno-Azanza et al., 2009; Moreno-Azanza, 2014) and El Horcajo (Trevijano, La Rioja, this work).

\begin{tabular}{ll}
\multicolumn{2}{c}{ Pochancalo 1 } \\
\hline \multicolumn{1}{c}{ Ootaxa } & \multicolumn{1}{c}{ Putative egg layer } \\
\hline Megaloolithus oosp. 1 & Sauropod dinosaurs \\
Megaloolithus oosp. 2 & Sauropod dinosaurs \\
Phaceloolithidae indet. & Megalosaur dinosaurs \\
& \\
Krokoolithes oosp. & Crocodiles \\
Testudoolithus oosp. & Turtles \\
\hline
\end{tabular}

dinosaur, on the base of embryonic remains from the Upper Jurassic of Portugal (Araujo et al., 2013). On the contrary, dinosaur eggshells of El Horcajo most probably belong to ornithopod dinosaurs and coelurosaurian theropods.

The main difference between El Horcajo and Pochancalo 1 is the depositional environment of both localities. Pochancalo 1 is a grey lutitic level, part of an avulsion deposit (crevasse splay and crevasse channel) within a fluvial domain (Gasca et al., 2012). On the other hand, although detailed sedimentological and taphonomical analyses of El Horcajo 1 have not yet been conducted, it was formed as an attritional assemblage in a palustrine depositional environment. Noticeable is that most of the eggshell bearing Barremian localities of Spain are deposited in such environments, and Megaloolithidae and Phaceloolithidae eggshells are yet to be known. All the available evidence points towards the direction of a faciesdependent composition of the ootaxic assemblages. Further examination of existing localities and, moreover, the discovering on new sites are needed to test this hypothesis.

\begin{tabular}{ll}
\multicolumn{1}{c}{ El Horcajo } \\
\hline \multicolumn{1}{c}{ Ootaxa } & \multicolumn{1}{c}{ Putative egg layer } \\
\hline $\begin{array}{l}\text { Guegoolithus turolensis } \\
\text { Prismatoolithidae indet. }\end{array}$ & $\begin{array}{l}\text { Ornithopod dinosaurs } \\
\text { Coelurosaurian theropods }\end{array}$ \\
Geckoolithidae indet. & Geckos \\
Krokoolithes oosp. & Crocodiles \\
Testudoolithidae indet. & Turtles \\
\hline
\end{tabular}

The Valanginian-Hauterivian age of the El Horcajo assemblage was an unexpected result of this work. Recent geological studies, including low scale geological mapping and chronostratigraphic correlations based of biostratigraphy of dasyclads and foraminifera and sequence stratigraphy resulted in a Barremian and most probably Aptian age for the Enciso Group (see Suárez-González et al., 2013 for an in-depth revision on the age of the Leza Formation and Enciso Group). The presence of Guegoolithus turolensis in the assemblage, which has been considered as a guide fossil for the early Barremian of the Iberian Chain (Moreno-Azanza et al., 2008, 2014c), also supports a late Lower Cretaceous age for the assemblage. Nevertheless, charophyte fructifications are more reliable marker fossils than dasyclads, foraminifera and eggshells in lacustrine and palustrine environments, especially for the Lower Cretaceous. Furthermore, the presence of samples Berriasian in age in the same stratigraphic log, 25 $\mathrm{m}$ below the El Horcajo locality, confirms an early Lower Cretaceous age for the assemblage. These results challenge 
two important hypotheses: 1) the tectono-sedimentary framework of the Enciso Group in the Trevijano area, which most probably presents a significantly older age than other outcrops of the Enciso Group; and 2) the reliability of Guegoolithus as a guide fossil, which has been invalidated with the new findings.

\section{CONCLUSIONS}

The El Horcajo site is a new eggshell assemblage located in the Enciso Group of the Cameros Basin of La Rioja. Based on the presence of the fructifications of the charophytes Atopochara trivolvis var. micranda and Atopochara trivolvis var. ancora, a Valanginian-Hauterivian age is proposed for this assemblage. This represents the oldest eggshell assemblage found in Spain. Only the Upper Jurassic localities of Portugal present an older age in the Iberian Peninsula.

Five different ootaxa have being identified in the assemblage: 1) the Spheroolithidae Guegoolithus turolensis; 2) a surprisingly thick Prismatoolithidae indet., with certain affinities to the oogenus Sankofa, that may represent a new oogenus and oospecies for this oofamily; 3) the Krokolithidae Krokolithes sp.; 4) recrystallized ?Testudoolithidae eggshells; and 5) ?Geckoolithidae eggshells of uncertain affinity.

The ootaxonomic list of El Horcajo differs from the other locality known in Spain for this age, in the presence of putatively ornithopod and coelurosaurian theropod eggshells and the absence of putatively sauropod and megalosauroid theropod eggshells. Otherwise, the association is similar to other younger localities found in similar facies all over the Iberian Chain. This may support a facies dependence of the composition of the ootaxa assemblages that must be tested with new evidence.

A new older and unexpected Valanginian-Hauterivian age of El Horcajo, based on charophyte association, is postulated. New sedimentological and stratigraphical work is needed to integrate these new data in the existing tectono-stratigraphic models of the Cameros Basin. Furthermore, this age invalidates the usefulness of Guegoolithus as a guide fossil.

\section{ACKNOWLEDGEMENTS}

This project was partially founded by the Sociedad Española de Paleontología and its program "Ayudas a la Investigación". This paper forms part of the projects CGL2013-46169-C2-1-P and CGL2014-53548-P, subsidized by the Spanish Ministerio de Economía y
Competitividad, the European Regional Development Fund, and the Government of Aragón ("Grupos Consolidados"). The authors would like to acknowledge the use of the Servicio General de Apoyo a la Investigación-SAI, Universidad de Zaragoza. Pablo Suárez González, from the Universidad Complutense de Madrid provided useful comments on an earlier version of this manuscript. We are grateful to Xabier Pereda Suberbiola and Albert García Sellés for their constructive comments, as well as to the editors Julio Aguirre and Gonzalo Jiménez for managing the paper, which really improved the final version of the manuscript.

\section{REFERENCES}

Amo Sanjuán, O., Canudo, J.I. \& Cuenca-Bescós, G. 2000. First record of elongatoolithid eggshells from the Lower Barremian (Lower Cretaceous) of Europe (Cuesta Corrales 2, Galve Basin, Teruel, Spain). First International Symposium on Dinosaur Eggs and Babies (eds Bravo, A.M. \& Reyes, T.), Extended Abstracts, Isona i Conca Dellà, pp. 7-14.

Araújo, R., Castanhinha, R., Sanders, M., Mateus, O., Hendrickx, C., Beckmann, F., Schell, N. \& Alves, L.C. 2013. Filling the gaps of dinosaur eggshell phylogeny: Late Jurassic theropod clutch with embryos from Portugal. Scientific Reports 3 (May); doi: 10.1038/srep01924.

Barta, D.E., Brundridge, K.M., Croghan, J.A., Jackson, F.D., Varricchio, D.J., Jin, X. \& Poust, A.W. 2014. Eggs and clutches of the Spheroolithidae from the Cretaceous Tiantai basin, Zhejiang Province, China. Historical Biology, 26, 183-194; doi: 10.1080/08912963.2013.792811.

Bravo, A.M., Huerta, P., Izquierdo Montero, L.A., Montero Huerta, D., Pérez Martínez, G., Torcida Fernández-Baldor, F. \& Urién Montero, V. 2006. Un nuevo yacimiento de cáscaras de huevo de dinosaurio de la provincia de Burgos, España (Maastrichtiense, Fm Santibañez del Val). Actas de las III Jornadas Internacionales sobre Paleontología de Dinosaurios y su Entorno (ed. Colectivo Arqueológico y Paleontológio de Salas), Salas de los Infantes, Burgos, 223-234.

Buscalioni, A.D., Fregenal, M.A., Bravo, A., Poyato-Ariza, F.J., Sanchiz, B., Báez, A.M., Cambra Moo, O., MartínClosas, C., Evans, S.E. \& Marugan Lobón, J. 2008. The vertebrate assemblage of Buenache de la Sierra (Upper Barremian of Serranía de Cuenca, Spain) with insights into its taphonomy and palaeocology. Cretaceous Research, 29, 687-710; doi: 10.1016/j.cretres.2008.02.004.

Calvo, J.O., Engelland, S., Heredia, S.E. \& Salgado, L. 1997. First record of dinosaur eggshells (?Sauropoda Megaloolithidae) from Neuquén, Patagonia, Argentina. Gaia, 14, 23-32.

Canudo, J.I., Gasca, J.M., Aurell, M., Badiola, A., Blain, H.-A., Cruzado-Caballero, P., Gómez-Fernández, D., Moreno-Azanza, M., Parrilla, J., Rabal-Garcés, R. \& 
Ruiz-Omeñaca, J.I. 2010. La Cantalera: an exceptional window onto the vertebrate biodiversity of the HauterivianBarremian transition in the Iberian Peninsula. Journal of Iberian Geology, 36, 295-324; doi: 10.5209/rev JIGE.2010.v36.n2.8.

Chiappe, L.M., Coria, R.A., Dingus, L., Jackson, F., Chinsamy, A. \& Fox, M. 1998. Sauropod dinosaur embryos from the Late Cretaceous of Patagonia. Nature, 396, 258-261; doi:10.1038/24370.

Dewaele, L., Tsogtbaatar, K., Barsbold, R., Garcia, G., Stein, K., Escuillié, F. \& Godefroit, P. 2015. Perinatal specimens of Saurolophus angustirostris (Dinosauria: Hadrosauridae), from the Upper Cretaceous of Mongolia. PLoS ONE, 10(10), e0138806; doi: 10.1371/journal. pone. 0138806.

Doublet, S. 2004. Contrôles tectonique et climatique de l'enregistrement stratigraphique dans un basin continental de rift: le basin de Cameros (Jurassique supérieur-Crétacé inferieur) provinces de Soria-La Rioja, Espagne. Ph.D. Thesis, Université de Bourgogne, 465 p (unpublished).

Gasca, J.M., Badiola, A., Canudo, J.I., Moreno-Azanza, M. \& Puértolas, E. 2012. La asociación de vertebrados fósiles del yacimiento Pochancalo 1 (ValanginienseHauteriviense, Villanueva de Huerva, Zaragoza, España). Actas de las V Jornadas Internacionales sobre Paleontología de Dinosaurios y su Entorno (eds Huerta, P., Torcida Fernández-Baldor, F. \& Canudo, J.I.). Colectivo Arqueológico y Paleontológico de Salas, Salas de los Infantes, 159-172.

Hirsch, K.F. 1985. Fossil crocodylian eggs from the Eocene of Colorado. Journal of Paleontology, 59, 531-542.

Hirsch, K.F. 1994. Upper Jurassic eggshells from the Western Interior of North America. In: Dinosaur Systematics: Perspectives and Approaches (eds Carpenter, K. \& Currie, P.), Cambridge University Press, Cambridge, 137-150.

Hirsch, K.F. 1996. Parataxonomic classification of fossil chelonian and gecko eggs. Journal of Vertebrate Paleontology, 16, 752-762.

Hirsch, K.F. \& Quinn, B. 1990. Eggs and eggshell fragments from the Upper Cretaceous Two Medicine Formation of Montana. Journal of Vertebrate Paleontology, 10, 491-511.

Horner, J.R. 1999. Egg clutches and embryos of two hadrosaurian dinosaurs. Journal of Vertebrate Paleontology, 19, 607-611; doi: 10.1080/02724634.1999.10011174.

Horner, J.R. \& Makela, R. 1979. Nest of juveniles provides evidence of family structure among dinosaurs. Nature, 282, 296-298; doi: 10.1038/282296a0.

Homer, J.R. \& Weishampel, D.B. 1996. A comparative embryological study of two ornithischian dinosaurs (correction). Nature, 3531, 103; doi: 10.1038/383103b0.

Izquierdo, L.A., Montero, D., Pérez, G. \& Urién, V. 1999. Macroestructura de los huevos de dinosaurios de La Rosaca (Burgos, España). I Jornadas Internacionales sobre Paleontología de Dinosaurios y su Entorno, Dossier y resúmenes, Salas de los Infantes, Burgos, p. 27.

Köhring, R. 1990. Fossile reptil-eirschalen (Chelonia, Crocodilia, Dinosauria) aus dem unterem Barremium von
Galve (provinz Teruel, SE Spanien). Paläontologische Zeitschrift, 64, 392-344.

Köhring, R. 1991. Lizard eggshells from the Lower Cretaceous of Cuenca Province, Spain. Palaeontology, 34, 237-240.

Köhring, R. \& Hirsch, K.F. 1996. Crocodylian and avian eggshells from the Middle Eocene of the Geiseltal, Eastern Germany. Journal of Vertebrate Paleontology, 16, 67-80.

López-Martínez, N. \& Vicens, E. 2012. A new peculiar dinosaur egg, Sankofa pyrenaica oogen. nov. oosp. nov. from the Upper Cretaceous coastal deposits of the Aren Formation, South-Central Pyrenees, Lleida, Catalonia, Spain. Palaeontology, 55, 325-339; doi: 10.1111/j.14754983.2011.01114.x.

Martín-Closas, C. 2000. Els Caròfits del Juràssic Superior i el Cretaci Inferior de la Península Ibèrica. Institut d'Estudis Catalans, Arxius de les Seccions de Ciències 125, Barcelona, 304 p.

Marzola, M., Russo, J. \& Mateus, O. 2015. Identification and comparison of modern and fossil crocodilian eggs and eggshell structures. Historical Biology, 27, 115-133; doi: 10.1080/08912963.2013.871009.

Mas, R., Alonso, A. \& Guimera, J. 1993. Evolución tectonosedimentaria de una cuenca extensional intraplaca: la cuenca finijurasica- eocretácica de Los Cameros (La Rioja-Soria). Revista de la Sociedad Geologica de España, 6, 129-144.

Mas, R., García, A. (Coord.), Mas, R., García, A., Salas, R., Meléndez, A., Alonso, A., Aurel, M., Badenas, B., Benito, M.I., Carenas, B., Garíia-Hidalgo, J.F., Gil, J. \& Segura, M. 2004. Segunda Fase de rifting: Jurásico SuperiorCretácico Inferior. In: Geología de España (ed. Vera, J.A.), Sociedad Geológica de España, Instituto Geológico y Minero, Madrid, 503-510.

Mikhailov, K.E. 1991. Classification of fossil eggshells of amniotic vertebrates. Acta Palaeontologica Polonica, 36, 193-238.

Mikhailov, K.E. 1997. Fossil and Recent eggshell in amniotic vertebrates; fine structure, comparative morphology and classification. Special Papers in Palaeontology, 56, 1-80.

Mikhailov, K.E. 2014. Eggshell structure, parataxonomy and phylogenetic analysis: some notes on articles published from 2002 to 2011. Historical Biology, 26, 144-154; doi: 10.1080/08912963.2013.829824.

Mikhailov, K.E., Bray, E.S. \& Hirsch, K.F. 1996. Parataxonomy of fossil egg remains (Veterovata): principles and applications. Journal of Vertebrate Paleontology, 16, 763-769.

Mateus, I., Mateus, H., Antunes, M.T., Mateus, O., Taquet, P., Ribeiro, V. \& Manuppella, G. 1997. Couvée, oeufs et embryons d'un dinosaure théropode du Jurassique supérieur de Lourinha (Portugal). Comptes Rendus de l'Académie des Sciences de Paris, Series IIA, Earth and Planetary Science, 325, 71-78; doi: 10.1016/S12518050(97)83275-2.

Moratalla, J.J. 1993. Restos indirectos de dinosaurios del registro español: paleoicnología de la cuenca de Cameros (Jurásico Superior - Cretácico Inferior) y Paleoología del 
Cretácico Superior. PhD Thesis, Universidad Autónoma de Madrid, 2 vol., 726 p (unpublished).

Moreno-Azanza, M. 2014. Los huevos fósiles de amniotas del Cretácico de la Península Ibérica: tafonomía, formación de la cascara y sistemática. Ph.D. Thesis, Universidad de Zaragoza. $280 \mathrm{p}$ (unpublished).

Moreno-Azanza, M., Canudo, J.I. \& Gasca, J.M. 2009. Fragmentos de cáscara de huevo de Megaloolithidae en el Cretácico Inferior de la provincia de Zaragoza (Formación Villanueva de Huerva, España). Actas de las IV Jornadas Internacionales sobre Paleontología de Dinosaurios y su Entorno (ed. Colectivo Arqueológico y Paleontológico de Salas), Salas de los Infantes, 253-262.

Moreno-Azanza, M., Canudo, J.I. \& Gasca, J.M. 2014b. Unusual theropod eggshells from the Early Cretaceous Blesa Formation of the Iberian range, Spain. Acta Palaeontologica Polonica, 59, 843-854; doi: 10.4202/ app.2012.0069.

Moreno-Azanza, M., Canudo, J.I. \& Gasca, J.M. 2014c. Spheroolithid eggshells in the Lower Cretaceous of Europe. Implications for eggshell evolution in ornithischian dinosaurs. Cretaceous Research, 51, 75-87; doi: 10.1016/j.cretres.2014.05.017.

Moreno-Azanza, M., Canudo, J.I. \& Gasca, J.M. 2015. Enigmatic Early Cretaceous ootaxa from Western Europe with signals of extrinsic eggshell degradation. Cretaceous Research, 56, 617-627; doi: 10.1016/j.cretres.2015.06.019.

Moreno-Azanza, M., Gasca, J.M., \& Canudo, J.I. 2008. Macroolithus turolensis como fósil guía para el Hauteriviense superior-Barremiense basal de Teruel. XXIV Jornadas de la Sociedad Española de Paleontología, Libro de Resúmenes, pp. 43-44.

Moreno-Azanza, M., Bauluz, B., Canudo, J.I., PuértolasPascual, E. \& Sellés, A.G. 2014a. A re-evaluation of aff. Megaloolithidae eggshell fragments from the uppermost Cretaceous of the Pyrenees and implications for crocodylomorph eggshell structure. Historical Biology, 26, 195-205; doi: 10.1080/08912963.2013.786067.

Oliveira, C.E.M., Santucci, R.M., Andrade, M.B., Fulfaro, V.J., Basílio, J.A.F. \& Benton, M. 2011. Crocodylomorph eggs and eggshells from the Adamantina Formation (Bauru Group) Upper Cretaceous of Brasil. Palaeontology, 54, 309-321; doi: 10.1111/j.1475-4983.2010.01028.x.

Omodeo-Salè, S., Guimerà, J., Mas, R. \& Arribas, J. 2014. Tectono-stratigraphic evolution of an inverted extensional basin: the Cameros Basin (north of Spain). International Journal of Earth Sciences, 103, 1597-1620; doi: 10.1007/ s00531-014-1026-5.

Omodeo-Salè, S., Salas, R., Guimerà, J., Ondrak, R., Mas, R., Arribas, J., Suárez-Ruiz, I. \& Martínez, L., 2015. Subsidence and thermal history of an inverted Late Jurassic-Early Cretaceous extensional basin (Cameros, North-central Spain) affected by very low- to low-grade metamorphism. Basin Research, doi: 10.1111/bre.12142.

Quijada, I.E., Suárez-González, P., Benito, M.I. \& Mas, R., 2013. New insights on stratigraphy and sedimentology of the Oncala Group (eastern Cameros Basin): implications for the paleogeographic reconstruction of Iberia at
Berriasian times. Journal of Iberian Geology, 39, 313334; doi: 10.5209/rev_JIGE.2013.v39.n2.42503.

Riveline, J., Berger, J.P., Feist, M., Martín-Closas, C., Schudack, M. \& Soulié-Märsche, I. 1996. European Mesozoic-Cenozoic charophyte biozonation. Bulletin de la Société géologique de France, 167, 453-468.

Ruiz-Galbán, A., Sevilla, P. \& Sanz, J.L. 2014. Microfósiles de los yacimientos barremienses de las "Hoces de Beteta" (Cuenca, España). Primeros resultados. In: New Insights on Ancient Life (eds Arreguín-Rodríguez, G., Colmenar, J., Díaz-Berenguer, E., Galán, J., Legarda-Lisarri, A., Parrilla-Bel, J., Puértolas-Pascual, E. \& Silva-Casal, R.). XII Encuentro de Jóvenes Investigadores en Paleontología (EJIP), Boltaña, Huesca, 109-112.

Salas, R., Guimerà, J., Mas, R., Martín-Closas, C., Meléndez, A. \& Alonso, A. 2001. Evolution of the Mesozoic central Iberian Rift System and its Cainozoic inversion (Iberian Chain). In: Peri-Thethyan Rift/Wrench Bassins and Passive Margins (eds Ziegler, P.A., Cavazza, W., Robertson, A.H.F. \& Crasquin-Soleau, S.). Mémoires du Muséum Nationale de l'Histoire Naturelle, Peri-Tethys Memoir 6, 186, 145-185.

Schudack, U. \& Schudack, M. 2009. Ostracod biostratigraphy in the Lower Cretaceous of the Iberian chain (Eastern Spain). Journal of Iberian Geology, 35, 141-168.

Sellés, A.G. 2012. Oological record of dinosaurs in southcentral Pyrenees (SW Europe): parataxonomy, diversity and biostratigraphical implications. PhD Thesis, Universitat de Barcelona, $231 \mathrm{pp}$ (unpublished).

Suárez-González, P., Quijada, I.E., Benito, M.I. \& Mas, R. 2013. Eustatic versus tectonic control in an intraplate rift basin (Leza Fm., Cameros Basin). Chronostratigraphic and paleogeographic implications for the Aptian of Iberia. Journal of Iberian Geology, 39, 285-312.

Suárez-González, P., Quijada, I.E., Benito Moreno, M.I. \& Mas, R. 2015. Sedimentology of ancient coastal wetlands: insights from a Cretaceous multifaceted depositional system. Journal of Sedimentary Research, 85, 95-117.

Suárez-González, P., Quijada, I.E., Mas, R. \& Benito, M.I. 2010. Nuevas aportaciones sobre la influencia marina y la edad de los carbonatos de la Fm. Leza en el sector de Préjano (SE de La Rioja). Cretácico Inferior, Cuenca de Cameros. Geogaceta, 49, 7-10.

Tanaka, K., Zelenitsky, D.K., Saegusa, H., Ikeda, T., DeBuhr, C.L. \& Therrien, F. 2016. Dinosaur eggshell assemblage from Japan reveals unknown diversity of small theropods. Cretaceous Research, 57, 350-363; doi: 10.1016/j. cretres.2015.06.002.

Tischer, G. 1966. Über die Wealden-Ablagerung und die Tektonik der östlichen Sierra de los Cameros in den nordwestlichen Iberischen Ketten (Spanien). Beihefte zum Geologischen Jahrbuch, 44, 123-164.

Varricchio, D.J., Jackson, F., Borlowski, J. \& Horner, J.R. 1997. Nest and egg clutches for the dinosaur Troodon formosus and evolution of avian reproductive traits. Nature, 385, 247-250; doi: 10.1038/385247a0.

Vianey-Liaud, M. \& López-Martínez, N. 1997. Late Cretaceous dinosaur eggshells from the Tremp basin, 
southern Pyrenees, Lleida, Spain. Journal of Paleontology, 71, 1157-1171.

Vyalov, S. 1972. The classification of the fossil traces of life. Proceedings of 24th International Geological Congress, Section 7, 639-649.

Zelenitsky, D.K. \& Hills, L.V. 1996. An egg clutch of Prismatoolithus levis oosp. nov. from the Oldman
Formation (Upper Cretaceous), Devil's Coulee, southern Alberta. Canadian Journal of Earth Sciences, 33, 11271131; doi: 10.1139/e96-085.

Zhao, Z. 1979. The advancement of research on the dinosaurian eggs in China. In: Mesozoic and Cenozoic Redbeds in Southern China. Beijing, Science Press, 30-40. 